\title{
Bacterial-induced release of inflammatory mediators by bronchial epithelial cells
}

\author{
O.A. Khair, R.J. Davies, J.L. Devalia
}

Bacterial-induced release of inflammatory mediators by bronchial epithelial cells. O.A. Khair, R.J. Davies, J.L. Devalia. C ERS Journals Ltd 1996.

ABSTRACT: This review focuses on bacterial induction and release of inflammatory cytokines and adhesion molecules by human bronchial epithelial cells, with special reference to Haemophilus influenzae, a pathogen commonly associated with chronic bronchitis. Studies investigating the mechanisms underlying bacterial colonization of the airways and bacterial-induced chronic airway inflammation have suggested that these are likely to involve localization of bacteria to the site(s) of infection in the respiratory tract and induction of a local airway inflammation resulting in the initiation of epithelial damage.

We have hypothesized that the gross airway epithelial damage observed in chronic infective lung disease is an indirect consequence of proteolytic enzymes and toxic oxygen radicals generated by large numbers of neutrophils infiltrating the airways. Furthermore, the infiltration and activation of the neutrophils is a consequence of increased release of proinflammatory mediators from the host respiratory epithelium, induced by bacterial products, such as endotoxin. This hypothesis is based on studies which have demonstrated that the concentrations of circulating cytokines, such as interleukin (IL)-8 and tumour necrosis factor- $\alpha$ (TNF- $\alpha$ ), which have profound effects on neutrophil activity, are increased in endotoxaemia and that airway epithelial cells are a rich source of these cytokines.

Support for this hypothesis is provided by studies of cultured human bronchial epithelial cells incubated either in the absence or presence of purified endotoxin preparations from nontypable and type b $\mathrm{H}$. influenzae strains which have demonstrated that these endotoxins lead to significantly increased expression and/or release of proinflammatory mediators, including IL-6, IL-8, TNF- $\alpha$ and intercellular adhesion molecule-1 (ICAM-1). Treatment of the cells with steroids can downregulate the expression and/or release of these inflammatory mediators. Additionally, these studies have demonstrated that culture medium collected from endotoxin-treated cultures, $24 \mathrm{~h}$ after treatment, significantly increases neutrophil chemotaxis and adhesion to human endothelial cells in vitro.

Eur Respir J., 1996, 9, 1913-1922.
Dept of Asthma and Allergic Respiratory Diseases, St. Bartholomew's and the Royal London School of Medicine and Dentistry, The London Chest Hospital, London, UK.

Correspondence: J.L. Devalia

Dept of Asthma and Allergic Respiratory Diseases

St. Bartholomew's and the Royal London School of Medicine and Dentistry

The London Chest Hospital

Bonner Road

London E2 9LX

UK

Keywords: Airway inflammation

bronchial epithelial cells cell adhesion molecules Haemophilus influenzae proinflammatory cytokines transcription factors

Received: March 41996

Accepted for publication March 181996
Clinical studies of patients with chronic bronchitis have shown that many exacerbations of the disease in these patients are associated with bacterial infection, with nonencapsulated Haemophilus influenzae being one of the most commonly isolated organisms [1]. In contrast, studies of septicaemia, pneumonia and systemic $H$. influen$z a e$ infections in children have suggested that these are the most common clinical manifestations of $H$. influenzae type $\mathrm{b}[2,3]$.

Several studies have established that nonencapsulated $H$. influenzae is present in the respiratory tract of the majority of patients with chronic bronchitis, and can be recovered occasionally from serial sputum cultures from virtually all chronic bronchitics [4]. Other studies have suggested that there is an association between purulence and the presence of nonencapsulated $H$. influenzae in sputum cultures, and that these bacteria can be isolated from the sputum more often during exacerbations than during symptom-free periods $[5,6]$. However, since these bacteria can be isolated from the sputum of chronic bronchitics during remission [7] and have also been shown to be common inhabitants of the normal human upper respiratory tract of up to $80 \%$ of healthy adults [1], their role in the pathogenesis of chronic bronchitis is not entirely clear.

The role of bacterial infection in chronic airway inflammation

Studies of pulmonary infections have demonstrated that there is a close relationship between bacterial load and neutrophil recruitment [8], and have suggested that neutrophils play an important role in the pathogenesis of chronic lung diseases, due to their ability to release a variety of oxidants and proteolytic enzymes capable of causing acute and chronic lung injury [9]. SMALLMAN et al. [10] have shown that the sol phase of purulent sputum, containing free elastolytic activity, caused gradual slowing of human ciliary beat frequency in vitro, and 
that this attenuation in ciliary beat frequency was prevented by the prior addition of $\alpha$-antiproteinase to the sputum.

Furthermore, some studies have demonstrated that bronchial secretions may also contain bacterial toxins, which can cause epithelial necrosis and disrupt ciliary ultrastructure [11]. Studies of bacterial lipopolysaccharide (LPS) have demonstrated that this is a major component of the outer membrane of Gram-negative bacteria, responsible for toxic manifestations of severe Gram-negative infections and generalized inflammation [12]. Animal studies have suggested that the effects of endotoxin may be mediated via proinflammatory cytokines such as interleukin (IL)-6, tumour necrosis factor- $\alpha$ (TNF- $\alpha$ ) and interferon- $\gamma$ (IFN- $\gamma)$, since neutralizing antibodies to these cytokines protected against the lethality of Escherichia coli endotoxin injected into the animals $[13,14]$. Indeed, studies in septic shock patients have demonstrated that the concentrations of circulating TNF- $\alpha$ were raised for several days in these patients and were associated with poor outcome, whilst stable or falling concentrations correlated with survival $[15,16]$. Similarly, other studies have demonstrated that soluble receptors for TNF- $\alpha$ are also increased in clinical sepsis and experimental E. coli endotoxaemia, and suggest that this may be a natural host defence mechanism, in which the soluble receptors would bind the free circulating TNF- $\alpha$ and thereby prevent or attenuate the biological activity of this cytokine $[17,18]$. More recently, van DEventer et al [19] have demonstrated that injection of human volunteers with low doses of $E$. coli endotoxin led to increased concentrations of IL-8 in the blood, 90 min after injection. Similarly, other studies of human volunteers challenged with purified endotoxin have shown that doses of $2-4 \mathrm{ng} \cdot \mathrm{kg}^{-1}$ endotoxin led to maximal increase in plasma concentrations of TNF, 90-120 min after challenge [20]. More recently, SANDSTRÖM et al. [21] have demonstrated that administration, by aerosol, of $25 \mu \mathrm{g} \mathrm{E}$. coli endotoxin into the lungs of healthy nonsmoking subjects led to nearly a 100 fold increase in neutrophils and a threefold increase in lymphocytes in bronchoalveolar lavage (BAL), collected from these individuals $3 \mathrm{~h}$ after endotoxin challenge [21]. Endotoxin treatment did not, however, affect the numbers of macrophages or mast cells in the BAL of these subjects (table 1). Collectively, these results suggest that the neutrophilic response observed in response to endotoxin challenge may be of greatest relevance in bacterial infections and possibly a consequence of endotoxin-induced increase in the concentrations of IL-8 and TNF- $\alpha$.

\section{The putative mechanisms of bacterial-induced chronic airway inflammation}

Studies in healthy individuals, however, have demonstrated that the initial interaction of inhaled bacteria occurs with mucus within the airway mucosa, and that local defences, such as the mucociliary system and local antibodies, clear these out efficiently [22]. READ et al. [23] have hypothesized that, in individuals whose primary airway defences are compromised (i.e. impaired mucociliary clearance and increased mucus production), a "vicious circle of events" results in chronic airway inflammation and damage as a consequence of the host-mediated response to bacterial infections. These authors have speculated that in cigarette smokers, patients with chronic bronchitis or bronchiectasis and those with recent viral infections, bacteria such as $H$. influenzae remain attached to mucus in the respiratory tract for longer periods and, thus, replicate and make surface contact with damaged epithelium more readily at the nonciliated sites. This allows adherence of the bacteria to receptors, which are either inaccessible or unavailable on normal epithelium, and facilitates colonization of respiratory tract epithelial surfaces, where localized release of ciliotoxins, endotoxins, proteolytic enzymes, etc. may compromise the host defence system further; i.e. impair ciliary function, stimulate mucus production, break down local immunoglobulins and impair phagocytic function [24-26]. This consequently leads to an environment conducive to contiguous spread of the bacterium and a host-mediated, predominantly neutrophilic, counter effect, which results in further damage.

Although some studies have demonstrated that bacteria can generate and release specific neutrophil chemoattractants [27], others have demonstrated that bacteria such as $H$. influenzae can also release compounds which inhibit neutrophil chemotaxis [28], thereby suggesting that neutrophil infiltration in response to direct stimulation by bacterial products may be a self-limiting process and, therefore, unlikely on its own to account for the gross neutrophil infiltration which is observed in chronic infective lung diseases.

We hypothesize that chronic neutrophil infiltration seen in infective lung disease is an indirect consequence of bacterial-induced synthesis and release, from the host airway epithelium, of potent proinflammatory mediators which directly or indirectly influence the activity of neutrophils. These mediators result predominantly in large numbers of neutrophils, and to a lesser extent other inflammatory cell types, trafficking into the bronchial tree and releasing a variety of proteolytic enzymes and toxic oxygen

Table 1. - Data on cell content in BALF before and $3 \mathrm{~h}$ after LPS inhalation

\begin{tabular}{|c|c|c|c|c|c|c|}
\hline & $\begin{array}{l}\text { Total } \\
\text { cells } \\
\times 10^{7} \cdot \mathrm{L}^{-1}\end{array}$ & $\begin{array}{c}\text { Total } \\
\text { neutrophils } \\
\times 10^{7} \cdot \mathrm{L}^{-1}\end{array}$ & $\begin{array}{c}\text { Total } \\
\text { lymphocytes } \\
\times 10^{7} \cdot \mathrm{L}^{-1}\end{array}$ & $\begin{array}{c}\text { Total } \\
\text { macrophages } \\
\times 10^{7} \cdot \mathrm{L}^{-1}\end{array}$ & $\begin{array}{l}\text { Lysozyme }+\mathrm{ve} \\
\text { macrophages } \\
\% \text { of macrophages }\end{array}$ & $\begin{array}{c}\text { Total } \\
\text { mast cells } \\
\times 10^{4} \cdot \mathrm{L}^{-1}\end{array}$ \\
\hline $\begin{array}{l}\text { Before exposure } \\
\text { Median } \\
\text { Interquartile range }\end{array}$ & $\begin{array}{c}6.8 \\
5.3-13.7\end{array}$ & $\begin{array}{c}0.06 \\
0.02-0.10\end{array}$ & $\begin{array}{c}0.49 \\
0.30-1.14\end{array}$ & $\begin{array}{c}5.9 \\
4.85-13.1\end{array}$ & $\begin{array}{c}7.5 \\
6.5-12.5\end{array}$ & $\begin{array}{c}0.06 \\
0.0-0.20\end{array}$ \\
\hline $\begin{array}{l}\text { After LPS exposure } \\
\text { Median } \\
\text { Interquartile range }\end{array}$ & $\begin{array}{c}21.6 \\
15.5-28.9\end{array}$ & $\begin{array}{c}8.7 \\
2.5-14.9\end{array}$ & $\begin{array}{c}1.67 \\
0.10-2.46\end{array}$ & $\begin{array}{c}10.1 \\
8.1-14.1\end{array}$ & $\begin{array}{c}5.0 \\
4.0-5.5\end{array}$ & $\begin{array}{c}0.29 \\
0.10-1.42\end{array}$ \\
\hline$p$-value & $<0.01$ & $<0.001$ & $<0.05$ & NS & $<0.02$ & NS \\
\hline
\end{tabular}

BALF: bronchoalveolar lavage fluid; LPS: lipopolysaccharide; NS: nonsignificant. (From SANDSTRÖM et al. [21] with permission). 
Air pollution, viral infection, cigarette smoke

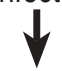

Impaired ciliary function

Increased mucus production

Airway mucosal damage

Bacteria attach to mucus

and damage epithelium

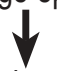

Bacterial products

(endotoxin, ciliotoxins, enzymes, etc)

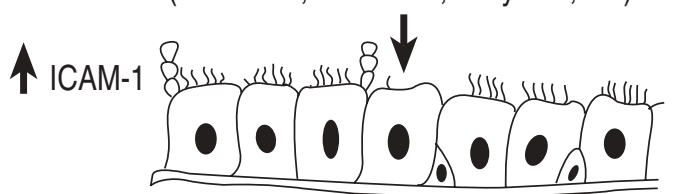

$\downarrow$

Proinflammatory cytokines

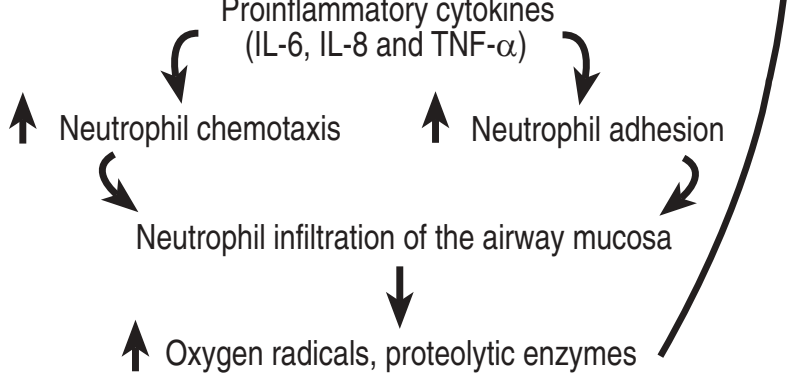

Fig. 1. - Putative interaction between airway epithelial cells and bacterial products in the amplification of neutrophil-induced airway epithelial damage. ICAM-1: intercellular adhesion molecule-1; IL: interleukin; TNF- $\alpha$ : tumour necrosis factor- $\alpha$.

radicals. In situations when the total load of these detrimental compounds is large enough to overwhelm the defence mechanisms which normally operate to limit the effect of these compounds, excessive mucus production and epithelial damage follows. Since activated neutrophils also have the capacity to synthesize and secrete IL-8 and other proinflammatory mediators, this becomes a selfperpetuating inflammatory process (fig. 1).

\section{The role of airway epithelial cells in the aetiology of airway inflammation}

The mechanisms responsible for the inflammatory cell influx in the central airways of patients with airway inflammation, such as those with chronic bronchitis, have not been well delineated. Although lung secretions, particularly in the presence of infection, have been shown to contain many neutrophil chemoattractants, the precise source of the factors initiating recruitment of neutrophils to the sites of infection is not well understood [29]. Whilst it is possible that bacteria themselves may generate some of these factors, there is increasing evidence to suggest that the airway epithelial cells may, indeed, be an important source and could provide a local mechanism to induce, amplify, or modulate on-going inflammation [30] (fig. 2).

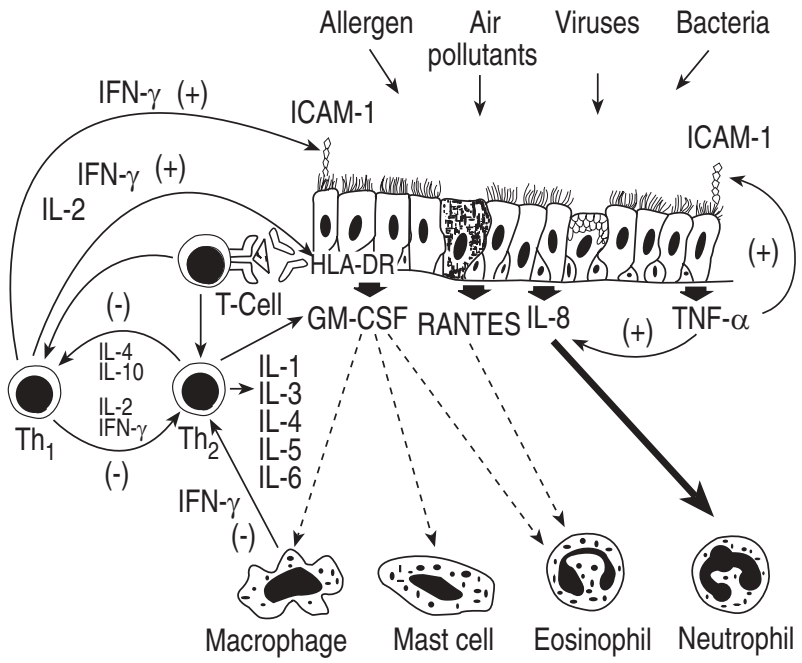

Fig. 2. - Schematic view of the role of epithelial cells in the modulation of airway inflammation. ICAM-1: intercellular adhesion molecule-1; IFN- $\gamma$ : interferon- $\gamma$; IL: interleukin; GM-CSF: granulocyte/macrophage colony-stimulating factor; TNF- $\alpha$ : tumour necrosis factor- $\alpha$; RANTES: factor regulated upon activation in normal T-cell, expressed and secreted; $\mathrm{TH}_{1}$ and $\mathrm{Th}_{2}$ : type 1 and type 2 T-helper cells. (Modified from Devalia and Davies [30]).

Studies from our laboratory have demonstrated that human airway epithelial cells are capable of expressing and generating specific cytokines, including IL-6, IL-8 and TNF- $\alpha$, which may play a role in activation and migration of neutrophils to sites of inflammation in the epithelium [31]. IL-6 is important in the induction of the acute phase response, augmentation of antibody production, and is released relatively early in the inflammatory response [32]. Studies of IL-8 have suggested that this cytokine has potent neutrophil activating properties, including neutrophil chemoattraction [33] and enhanced neutrophil binding at the site of inflammation [34], of which the latter may be a consequence of IL-8-induced expression of CD11b/CD18 (Mac-1) on the surface of neutrophils [34]. Recent studies by CROMwELL et al [35] have demonstrated that human bronchial epithelial cells are capable of generating IL-8 and that the expression of this cytokine may be upregulated by TNF- $\alpha$, a multifunctional cytokine shown to be active in increasing epithelial permeability in vitro [36], and increasing the expression of intercellular adhesion molecule-1 (ICAM-1) [37]. Indeed, studies of human bronchial epithelial cells have demonstrated that these are also capable of expressing ICAM-1 [38], a member of the immunoglobulin supergene family, which is itself important due to its role in the recruitment and migration of neutrophils and eosinophils [39].

\section{$H$. influenzae stimulates the release of proinflamma- tory cytokines from human bronchial epithelial cells}

Whilst the majority of studies of bacterial endotoxins have concentrated on the effects of $E$. coli endotoxin, there are comparatively few studies with endotoxin from the nontypable strains of $H$. influenzae, which are the most important colonizing strains isolated in chronic bronchitis. 
We have cultured human bronchial epithelial cells, as explant cultures on microporous membranes, and investigated the effect of purified endotoxins from a nontypable (NCTC 8143) and type b (NCTC 8467) H. influenzae strains, on epithelial permeability and expression and release of proinflammatory cytokines and ICAM-1 in these cell cultures.

Our studies demonstrated that the endotoxin from both strains of $H$. influenzae had no adverse effect on epithelial cell membrane integrity of the epithelial cultures, as indicated by a lack of difference between the permeability coefficients of control untreated cultures and cultures incubated for $24 \mathrm{~h}$ in the presence of $10-100 \mathrm{pg} \cdot \mathrm{mL}^{-1}$ endotoxin. Indeed, both endotoxin preparations led to an initial increase in the electrical resistance of the cultures [40], suggesting that the permeability of the cultures was initially decreased rather than increased. This may be a consequence of an increase in cell volume, possibly resulting from chloride channel modulation [41], and/or changes in cell junctional complexes. Studies in our laboratory have demonstrated that incubation of epithelial cell cultures in the presence of histamine, a compound we have shown previously to be synthesized by $H$. influenzae and several other bacterial species [42, 43], leads to significant increase in the length of desmosomes present between adjacent cells [44]. Collectively, these studies suggest that the initial decrease in epithelial cell permeability observed in response to noxious compounds may be a naturally occurring protective mechanism, which serves primarily to preserve the integrity of the epithelium, but may be overcome by continuous exposure to these compounds.

Overall, these findings are in accordance with the findings of WIENER-KORNISH et al. [45], who have investigated the effect of $E$. coli endotoxin on sheep lung epithelium in vivo. These authors demonstrated that despite leading to a marked increase in interstitial pulmonary oedema and the number of neutrophils in the alveolar airspaces, E. coli endotoxin did not alter the alveolar epithelial permeability, as indicated by a lack of bidirectional movement of 125 I-labelled albumin across the alveolar epithelium. Furthermore, these authors demonstrated that treatment with $E$. coli endotoxin did not lead to any detrimental morphological changes in the alveolar epithelium.

Our studies have also demonstrated that $H$. influenzae endotoxin significantly increases the release of a number of proinflammatory cytokines, including IL-6, IL-8, TNF- $\alpha$, from human bronchial epithelial cell cultures [40]. Release of IL-8 and TNF- $\alpha$ was increased twofold and threefold, respectively, $24 \mathrm{~h}$ after treatment of the cultures with $100 \mu \mathrm{g} \cdot \mathrm{mL}^{-1}$ endotoxin from the nontypable $H$. influenzae, compared with control untreated cultures (fig. 3). Incubation of these cultures in the presence of $10^{-5} \mathrm{M}$ hydrocortisone and $0.1-10 \mu \mathrm{g} \cdot \mathrm{mL}^{-1}$ erythromycin significantly attenuated the endotoxin-induced release of these cytokines $[40,46]$. Incubation of the epithelial cultures in the presence of endotoxin from the type $b$ strain, however, led to a 65 fold increase in the release of IL- 8 and a fivefold increase in the release of TNF- $\alpha$ (fig. 3). In contrast, analysis of the culture medium from $H$. influenzae endotoxin-treated cultures revealed that the release of granulocyte/macrophage colony-stimulating factor (GM-CSF) and the factor regulated on activation in normal T-cells expressed and secreted (RANTES),
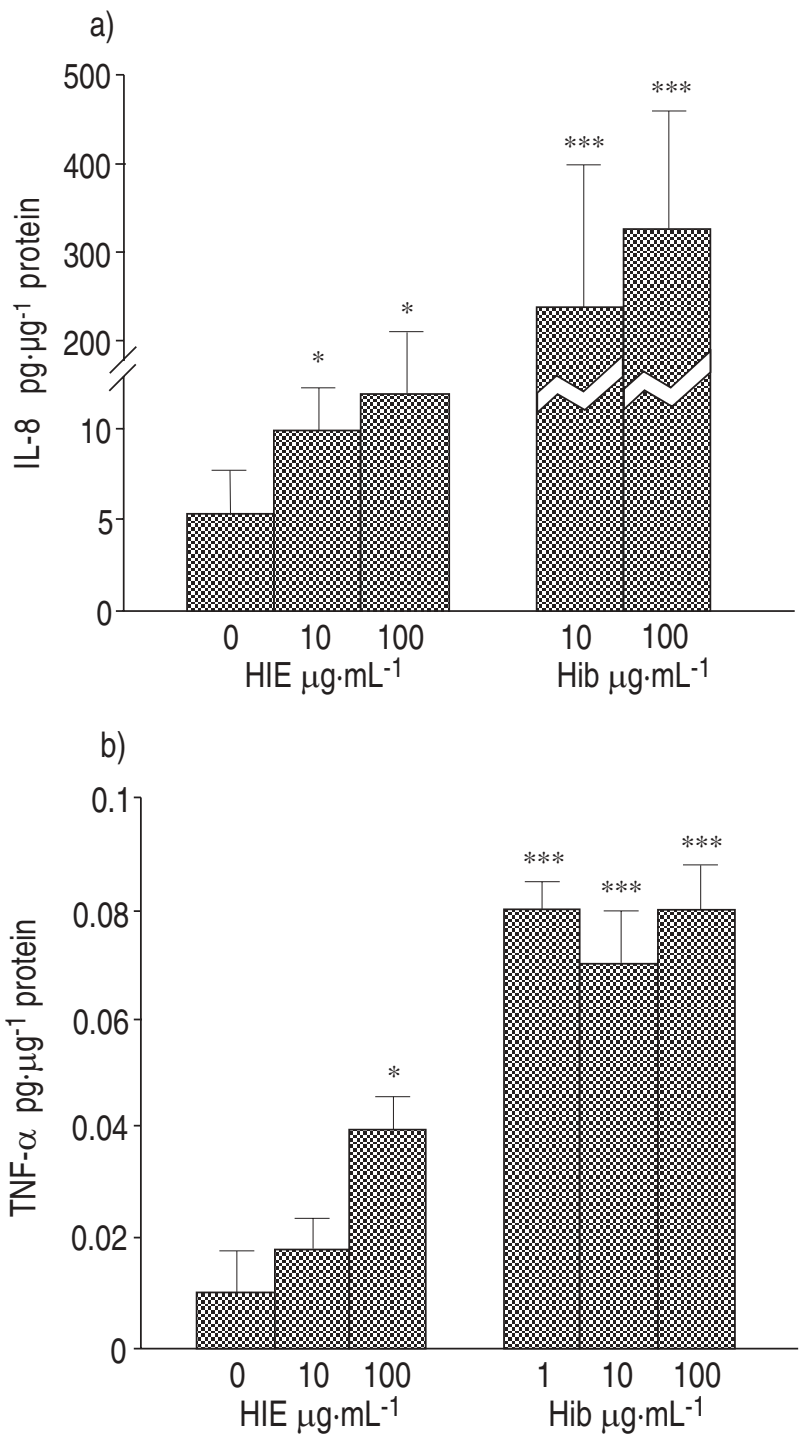

Fig. 3. - The effect of nontypable $H$. influenzae endotoxin (HIE) and type b $H$. influenzae (Hib) endotoxin on the release of: a) IL-8; and b) TNF- $\alpha$ by human bronchial epithelial cell cultures. Results are expressed as mean \pm SEM ( $\mathrm{n}=6$ at each concentration). *: $\mathrm{p}<0.05 \mathrm{vs}$ untreated cells; ***: $\mathrm{p}<0.001$ vs HIE-treated cells. For further definitions see legend to figure 1. (Modified from KHAIR et al. [40]).

cytokines known to have potent eosinophil chemotactic and activating properties, was not significantly increased. However, studies investigating the expression of ICAM-1 on epithelial cells demonstrated that the nontypable $H$. influenza endotoxin also upregulated the expression of ICAM-1 on these cells and that incubation of the cells in the presence of $10^{-5} \mathrm{M}$ hydrocortisone significantly attenuated the expression of this cell adhesion molecule (fig. 4).

Our findings are in agreement with those of others, who have also demonstrated that steroids, at concentrations of $10^{-7}$ to $10^{-5} \mathrm{M}$, can decrease the release of cytokines and expression of ICAM-1 in cultured epithelial cells and bronchial epithelial cell lines in vitro [47, 48].

Numerous activities have been ascribed to IL-6, including its ability to contribute to the stimulation of humoral and cellular defence mechanisms [49]. Studies by HEREMANS et al. [50] have suggested that IL-6 may also 


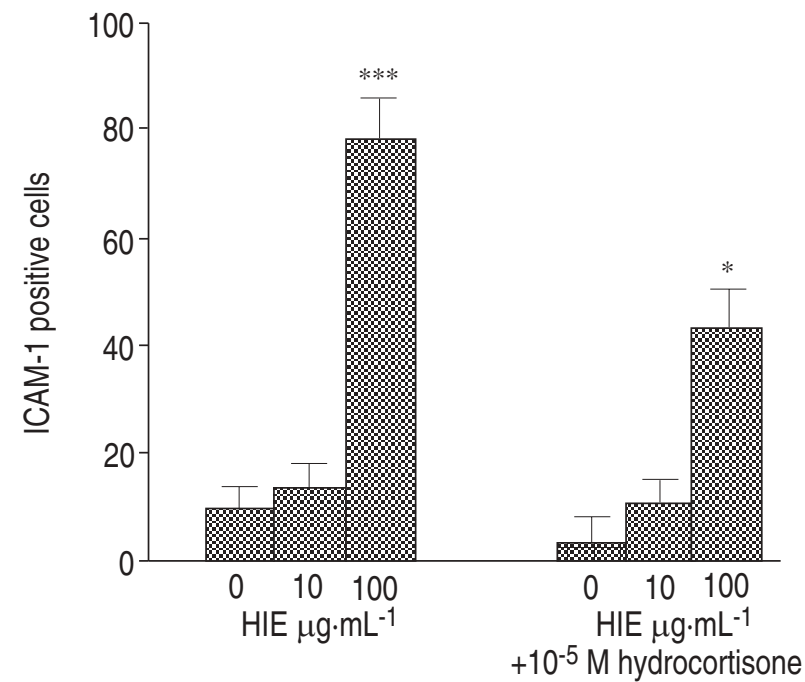

Fig. 4. - Effect of nontypable $H$. influenzae endotoxin (HIE) on the expression of surface ICAM-1 by human bronchial epithelial cell cultures and the influence of $10^{-5} \mathrm{M}$ hydrocortisone. Results are expressed as mean $\pm \operatorname{SEM}(\mathrm{n}=6$ at each concentration). $* * *: \mathrm{p}<0.001$ vs untreated cells; *: p<0.05 vs cells treated with $100 \mu \mathrm{g} \cdot \mathrm{mL}^{-1} \mathrm{HIE}$ alone. ICAM1: intercellular adhesion molecule-1. (Modified from KHAIR et al. [40]).

be involved in endotoxin-mediated reactions, since anti-IL6 antibodies were found to protect mice against the generalized endotoxin-elicited Schwartzman reaction. DEHOUX et al. [51] have reported that during unilateral community-acquired pneumonia, the inflammatory response is localized within the human lung, and is limited to the site of infection, with locally enhanced production of TNF$\alpha$, IL-1 $\beta$, and IL-6. Similarly, Boutten et al. [52] have demonstrated that IL-8 levels in bronchoalveolar lavage fluid (BALF) from the involved lung of patients with unilateral community-acquired pneumonia are also increased and that locally increased levels of IL-8 are correlated with neutrophil counts and with total and free elastase concentrations. SMiтh et al. [53] and DOHERTY et al. [54], have investigated the effects of $E$. coli endotoxin injected into rats and mice, respectively, and have demonstrated that this results in a significant increase in serum TNF- $\alpha$ activity. The studies of DOHERTY et al. [54] extended these observations by showing that specific neutralizing antibodies both to TNF- $\alpha$ and interferon-gamma $($ IFN- $\gamma$ ) protected the animals against the lethality of the $E$. coli endotoxin and suggested that TNF- $\alpha$ and IFN- $\gamma$ may be acting synergistically to potentiate the toxicity of this endotoxin. Studies of TNF- $\alpha$ have shown that this is a proximal mediator in the cytokine cascade, which appears in the circulation of several species as a brief early peak after infusion of bacteria or bacterial lipopolysaccharides and induces secondary cytokines, such as IL1, IL-6 and IL-8 $[55,56]$.

To investigate whether the cytokine profile induced by nontypable $H$. influenzae endotoxin was a direct effect or secondary to endotoxin-induced release of TNF- $\alpha$, we investigated the effect of TNF- $\alpha$ monoclonal neutralizing antibody on endotoxin-associated release of IL-6, IL-8 and soluble ICAM-1 (sICAM-1). These studies demonstrated that although TNF- $\alpha$ neutralizing monoclonal antibody significantly reduced the release of IL-6 and sICAM-1, this did not block the release of IL-8, from bronchial epithelial cell cultures. These results are contrary to the findings of VAN ZEE et al. [57], who have shown that levels of IL-6 and IL-8 in baboons with septic shock and sublethal endotoxaemia parallel one another and peak after TNF- $\alpha$, suggesting that TNF- $\alpha$ may induce the synthesis of both these cytokines. However, our results are in keeping with the findings of DeForGE et al. [58], who have investigated the release of cytokines in LPS-stimulated human whole blood. These authors have demonstrated that the synthesis of IL- 8 messenger ribonucleic acid (mRNA) and protein in the blood followed a biphasic pattern, and that this was not inhibited by addition of anti-TNF, anti-IL- $1 \alpha$ and anti-IL- $1 \beta$ antibodies, either alone or in combination, in the primary phase, but was substantially reduced in the secondary phase (fig. 5). These results suggest that IL-8 release in the primary phase was a result of direct stimulation by LPS, and in the secondary phase a result of induction by TNF- $\alpha$ and/or IL-1.
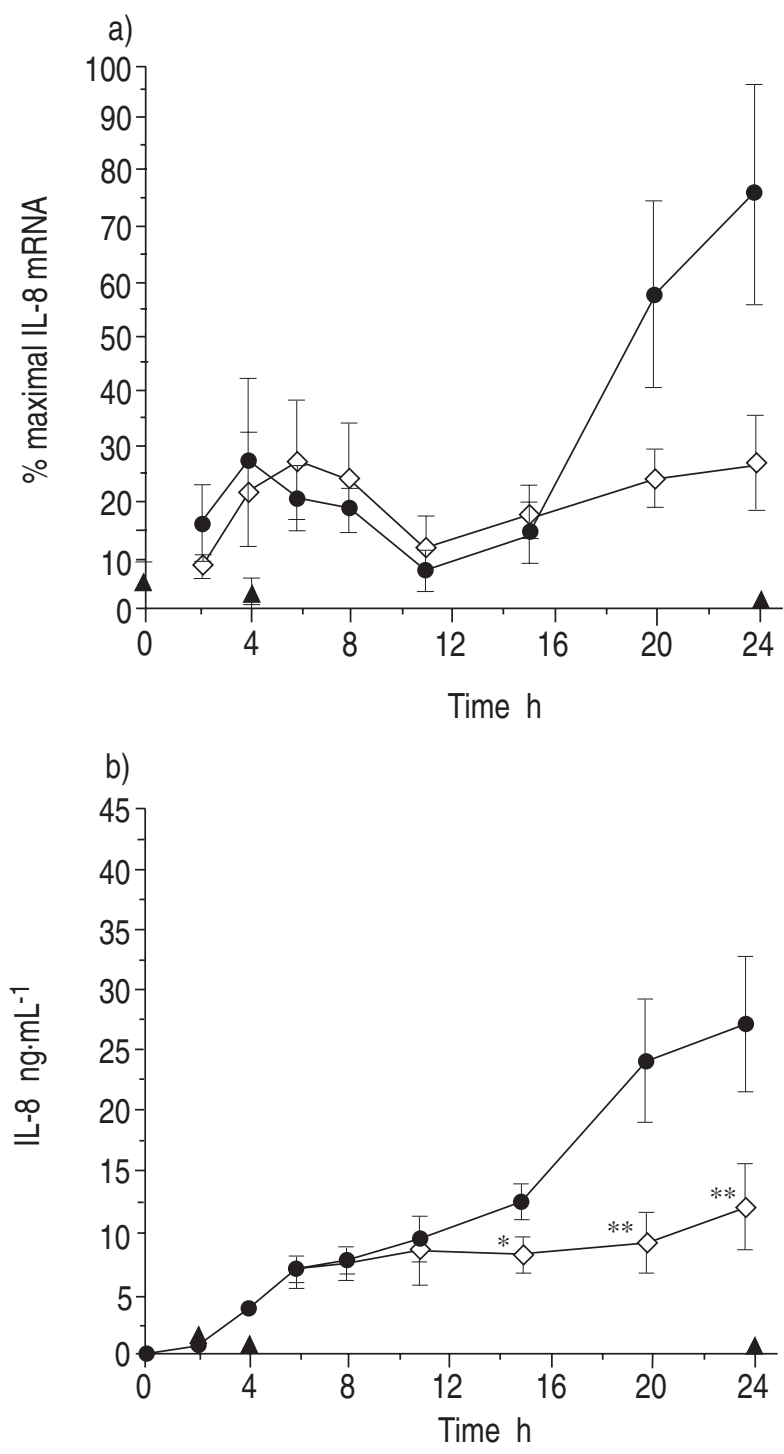

Fig. 5 - Inhibition of the second phase of: a) IL-8 mRNA expression; and b) IL-8 production in human whole blood, by anti-TNF and anti-IL-1 antibodies. (Modified from DeForge et al. [58]). $\longrightarrow$ : LPS + control antibody; $\longrightarrow \longrightarrow$ : LPS + anti-TNF- $\alpha+$ anti-IL-1; $\Delta$ : control. mRNA: messenger ribonucleic acid; LPS: lipopolysaccharide; *: $\mathrm{p}<0.007$ vs LPS + control antibody; **: $\mathrm{p}<0.001$ vs LPS + control antibody. For further definitions see legend to figure 1 . 
Overall, the finding that $H$. influenzae endotoxin induced significant release of IL-6, IL- 8 and TNF- $\alpha$ and increased the expression of ICAM-1 in human bronchial epithelial cell cultures may be of particular importance in bacterial-induced airway inflammation, since these mediators have been shown to exert a significant influence on neutrophil activity $[32,35,37]$. Additionally, since $H$. influenzae endotoxin was not shown to affect the synthesis and release of epithelial GM-CSF or RANTES, which influence primarily the activity of eosinophils [59, 60], these studies suggest that the effects of endotoxin are likely to be selective and directed towards synthesis and release of mediators that increase neutrophil recruitment and infiltration of the airways. Since endotoxin from type $\mathrm{b} H$. influenzae was also shown to lead to a much greater release of IL-8 and TNF- $\alpha$ than endotoxin from the nontypable strain of $H$. influenzae, this may be of particular significance and could explain the differences in the pathogenicity of the two strains. Type b $H$. influenzae is a more virulent organism associated with more severe and invasive infections, such as meningitis, pneumonia, epiglottitis and septic arthritis, in which bacteraemia is a prominent feature [61]. In contrast, nontypable strains lead to less severe infections resulting from proliferation and contiguous spread of the bacteria within the respiratory tract, such as otitis media, sinusitis and lower respiratory tract infections, including infective exacerbations of chronic bronchitis [62].

\section{Molecular mechanisms underlying endotoxin-induced proinflammatory cytokine synthesis}

Studies with isolated monocytes and alveolar macrophages have demonstrated that endotoxin-induced synthesis and release of inflammatory cytokines including IL-6, IL-8 and TNF- $\alpha$, from these cells is mediated via the cell membrane-bound CD14 receptor and that CD14 receptor activation may occur either in the absence or presence of specific LPS binding proteins (LBP) in the serum $[63,64]$. Studies, particularly of LPS-induced TNF$\alpha$ synthesis, have demonstrated that there is a threefold increase in the transcriptional activity and a 100 fold increase in cellular mRNA content [65].

Some studies, however, have demonstrated that although some cell types do not express CD14, they still have the ability to respond to endotoxin [66]. Studies by NAKAMURA et al. have demonstrated that LPS-induced $\mathrm{Ca}^{2+}$ increase in platelets and platelet aggregation can be blocked by selective platelet-activating factor (PAF) receptor antagonists, and suggest that there may be cross-reactivity between the LPS and the PAF receptors. Preliminary studies in our laboratory have also demonstrated that the bronchial epithelial cells do not express CD14, and suggest that the effects of $H$. influenzae endotoxin noted in our model may be mediated through a direct effect on epithelial cells or via an alternate cell membrane receptor, such as PAF receptors. Whilst some studies have demonstrated that PAF receptors are expressed on the airway epithelial cells in animals $[68,69]$, to our knowledge there is no report of the expression of PAF receptors on human airway epithelial cells.
Although LPS-induced signal transduction pathways leading to synthesis of inflammatory cytokines have not been fully elucidated, studies in monocytes and macrophages have suggested that these are likely to involve both cytoplasmic and nuclear components, including phospholipase C (PLC), protein kinase C (PKC) and transcription factors [70, 71]. It is thought that LPS-stimulated changes in cytosolic $\mathrm{Ca}^{2+}$, resulting from activation of PLC, may play a role in the regulation of gene expression, via modulation of PKC activity [72], which itself influences the activation of specific transcription factors [73]. Muegge and Durum [74] have reviewed the role of transcription factors and suggested that these are "third messengers", whose synthesis can be modulated by specific cytokines and which influence the expression of other cytokine genes by interacting with specific elements in the gene regulatory regions. Studies of transcriptional regulation of the TNF- $\alpha$ gene in monocytes have suggested that the promoter region of this gene contains binding sites for the transcription factors activating protein (AP)-1, AP-2 and nuclear factor-kappa B (NFkB) [75], and that LPS- induced transcription of this gene may be mediated by synthesis and activation of $c$-jun protein, a transcription factor that is essential for the transcriptional activation of the AP-1-responsive genes [76]. Indeed, BOYLE et al. [77] have suggested that increased binding of the AP-1 transcription factor complex to deoxyribonucleic acid (DNA) in human epithelial and fibroblast cell lines is a consequence of PCK-mediated dephosphorylation of the $c$-jun protein. Similarly, studies of the human IL-8 gene have demonstrated that this also contains potential binding sites for transcription factors AP-1, AP-2, NFкB, and NF-IL-6-like factor [78]. Whilst some studies have demonstrated that activation of NFKB and NF-IL-6-like factor is essential for induction of IL- 8 by mediators such as IL-1, TNF- $\alpha$ and phorbol myristate acetate (PMA) [79], others have demonstrated that binding of the glucocorticoid-receptor complex to the AP-1 factor leads to inhibition of IL-8 synthesis [80-82].

To our knowledge, there are no studies of the mechanisms underlying $H$. influenzae endotoxin mediated regulation of the genes encoding the inflammatory cytokines. We have studied the effect of $H$. influenzae endotoxin on the expression of $c$-fos, $c$-jun, and NFKB in human bronchial epithelial cells by immunostaining, followed by quantification of the percentage of total positively stained cells in the cultures by colour image analysis. Our studies have demonstrated that the expression of all these transcription factors was significantly upregulated in cultures incubated in the presence of $H$. influenzae endotoxin, when compared with control untreated cultures. Moreover, preincubation of the cultures with hydrocortisone or erythromycin blocked the endotoxin-induced expression of these factors (fig. 6).

\section{The biological relevance of $\boldsymbol{H}$. influenzae endotoxin-induced release of proinflammatory cytokines}

Despite increasing evidence for the role of airway epithelial cells in the generation of proinflammatory mediators, there is comparatively little information on the biological relevance of their release from epithelial cells, 

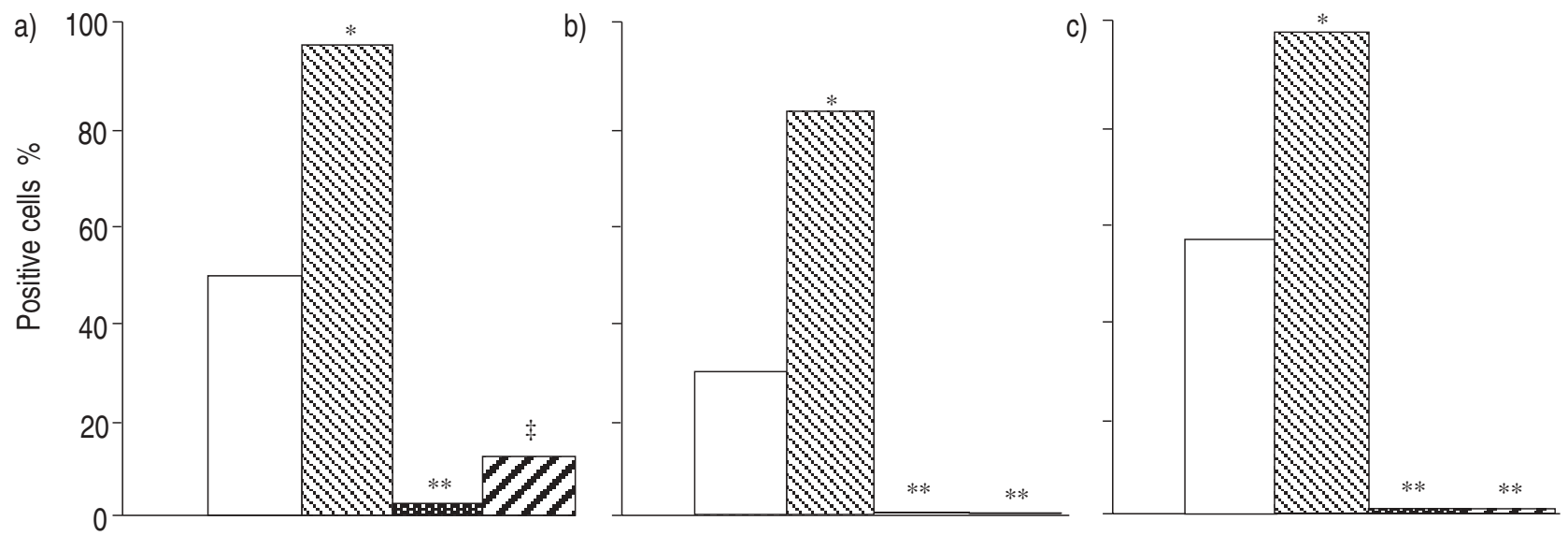

Fig. 6. - Effect of H. influenzae endotoxin (HIE) on the expression of: a) $c$-fos; b) $c$-jun; and c) nuclear factor-kappaB (NFKB) by human bronchial epithelial cell cultures and the influence of hydrocortisone $\left(10^{-5} \mathrm{M}\right)$ and erythromycin $\left(1 \mathrm{\mu g} \cdot \mathrm{mL}^{-1}\right)$. Results are expressed as mean \pm SEM $(\mathrm{n}=6$ at each concentration). *: $\mathrm{p}<0.05 \mathrm{vs}$ untreated control cells; **: $\mathrm{p}<0.001$ vs cells treated with $100 \mu \mathrm{g} \cdot \mathrm{mL}^{-1} \mathrm{HIE}$ alone; $\neq: \mathrm{p}<0.05$ vs cells treated with $100 \mu \mathrm{g} \cdot \mathrm{mL}^{-1} \mathrm{HIE}$ alone). $\square$ : control; $\$$ : HIE; 眀㽗 : HIE + hydrocortisone; 2 : HIE + erythromycin

either constitutively or following stimulation, in airway inflammation. We have investigated the effect of culture medium collected from confluent bronchial epithelial cell cultures incubated for $24 \mathrm{~h}$ (conditioned medium) in the presence or absence of $100 \mu \mathrm{g} \cdot \mathrm{mL}^{-1} \mathrm{H}$. influenzae endotoxin, on neutrophil chemotaxis and adhesion to human endothelial cells in vitro.

Neutrophil chemotaxis in response to conditioned medium from $H$. influenzae endotoxin-treated and untreated cultures was assessed by a modification of the Boyden chamber technique [83]. These studies demonstrated that conditioned medium from the endotoxin-treated cultures increased the chemotaxis of neutrophils twofold, when compared with conditioned medium from untreated cultures, and that this increase in neutrophil chemotaxis was blocked by treatment of the epithelial cell cultures with $1 \mu \mathrm{g} \cdot \mathrm{mL}^{-1}$ erythromycin [46]. More recent findings from our laboratory have indicated that the $H$. influenzae endotoxin-induced increase in neutrophil chemotaxis can also be blocked by the addition of IL- 8 monoclonal neutralizing antibody to the conditioned medium, and suggest that IL-8 is most likely to be involved in this process. This is in agreement with the findings of others, who have also demonstrated that this cytokine primarily influences neutrophil activation [84]. Although others have also demonstrated that epithelial cell derived mediators are chemotactic towards neutrophils $[85,86]$, and indeed other cell types including lymphocytes $[87,88]$ and monocytes $[86,89]$, in vitro, the majority of these studies have employed animal models.

Similarly, the effect of conditioned medium on neutrophil adherence was investigated by estimating the number of neutrophils adhering to human endothelial cell cultures established from cell line ECV304 (European Collection of Animal Cell Cultures, Porton Down, UK) and preincubated in the presence of conditioned medium from $H$. influenzae endotoxin-treated and untreated cultures, for $6 \mathrm{~h}$ at $37^{\circ} \mathrm{C}$. These studies demonstrated that adherence of neutrophils to endothelial cells preincubated with conditioned medium from endotoxin-treated epithelial cell cultures was significantly increased, when compared with neutrophil adherence to endothelial cells preincubated with conditioned medium from untreated cultures and, like neutrophil chemotaxis, was blocked by treatment of the epithelial cell cultures with $1 \mu \mathrm{g} \cdot \mathrm{mL}^{-1}$ erythromycin [46]. Subsequent studies investigating the effect of addition of anti-TNF- $\alpha$, anti-ICAM-1, and anti-E-selectin neutralizing monoclonal antibodies to the condition medium from the endotoxin-treated cultures have demonstrated that these antibodies blocked the endotoxin-induced adherence of neutrophils to endothelial cells, and suggest that neutrophil adhesion to endothelial cells is likely to be mediated via the expression of cell adhesion molecules such as ICAM-1 and E-selectin, on endothelial cells. Furthermore, the expression of these adhesion molecules was likely to be influenced by epithelial cell derived cytokines, such as TNF- $\alpha$.

Our findings of the regulatory role of bronchial epithelial cell-derived TNF- $\alpha$ in the expression of endothelial cell adhesion molecules and their involvement in the adherence of neutrophils are in accordance with the findings of others. SCHLEIMER et al. [90] have investigated the role of different adhesion molecules expressed on human vascular endothelial cells, in adherence of eosinophils, basophils and neutrophils and demonstrated that increased expression of endothelial vascular cell adhesion molecule-1 (VCAM-1), but not ICAM-1 or E-selectin, was paralleled by an increased adherence of eosinophils and basophils, but not neutrophils. These results suggest that ICAM-1 and E-selectin, but not VCAM-1, are involved in the adherence of neutrophils to endothelial cells. BOCHNER et al. [91] have investigated the effect of IL$1 \beta$, a cytokine with several biological effects similar to TNF- $\alpha$, on the adherence of neutrophils to human umbilical vein endothelial cells and have demonstrated that this cytokine significantly increases the adherence of neutrophils to endothelial cells.

In conclusion, our studies have demonstrated that human airway epithelial cells are capable of expressing and releasing potent proinflammatory cytokines and adhesion molecules, which play a prominent role in inflammation of the airways. Our finding that the expression and release from the epithelial cells of mediators which influence the activity of neutrophils is significantly enhanced by endotoxin from $H$. influenzae, and possibly other bacterial species, suggests that an interaction between bacterial products and airway epithelial cells is likely to play an important role in the development of bacterial-induced 
respiratory disease. Indeed, we have demonstrated that $H$. influenzae endotoxin-induced release of the inflammatory mediators from the bronchial epithelial cells in vitro, parallels increased neutrophil activation (chemotaxis and adhesion) in vitro. This gives credence to the hypothesis that gross neutrophil infiltration of the airway epithelium observed in chronic infective lung conditions is likely to be an indirect consequence of bacterial compounds, such as endotoxin, which augment the synthesis and release of inflammatory mediators from the host airway tissue.

\section{References}

1. Moxon ER. The carrier state: Haemophilus influenzae. J Antimicrob Chemother 1986; 18 (Suppl A): 17-24.

2. Turk DC. The patogenecity of Haemophilus influenzae. J Med Microbiol 1984; 18: 1-16.

3. Musher DM, Kubitschek KR, Crennan J, Baughn RE. Pneumonia and acute febrile tracheobronchitis due to Haemophilus influenzae. Ann Intern Med 1983; 99: 444-450.

4. Gump DW, Phillips CA, Forsyth BR, McIntosh FK, Lamborn KR, Stouch WH. Role of infection in chronic bronchitis. Am Rev Respir Dis 1978; 113: 465-473.

5. Tager I, Speizer FE. Role of infection in chronic bronchitis. N Engl J Med 1975; 292: 563-671.

6. Murphy TF, Apicella MA. Nontypable $H$ influenzae: a review of clinical aspects, surface antigens and the human immune response to infection. Rev Infect Dis 1987; 9: $1-15$.

7. Elis DA, Anderson IME, Stewart SM, Calder J, Crofton JW. Exacerbation of chronic bronchitis: exogenous or endogenous infections? Br J Dis Chest 1978; 72: 115-121.

8. Toews GB, Gross GN, Pierce AK. The relationship of inoculum size to lung bacterial clearance and phagocytic cell response in mice. Am Rev Respir Dis 1979; 120: $559-566$.

9. Rodriguez JR, Seals JE, Radin A, Lin JS, Mandl I, Turino GM. Neutrophil lysosomal elastase activity in normal subjects and in patients with chronic obstructive pulmonary disease. Am Rev Respir Dis 1979; 119: 409-517.

10. Smallman LA, Hill SL, Stockley RA. Reduction of ciliary beat frequency in vitro by sputum from patients with bronchiectasis: a serine proteinase effect. Thorax 1984; 39: 663-667.

11. Wilson R, Roberts D, Cole PJ. Effects of bacterial products on human ciliary function in vitro. Thorax 1985; 40: $125-131$.

12. Manthous CA, Hall JB, Samsel RW. Endotoxin in human disease. Part 2. Biologic effects and clinical evaluations of anti-endotoxin therapies. Chest 1993; 104: 1872-1881.

13. Smith EF, Slivjak MJ, Bartus JO, Esser KM. SK\&F inhibits tumor necrosis factor formation and improves survival in endotoxemic rats. J Cardiovasc Pharm 1991; 18: 721-728.

14. Doherty GM, Lange JR, Langstein HN, Alexander HR, Buresh CM, Norton JA. Evidence for IFN-gamma as a mediator of the lethality of endotoxin and tumor necrosis factor-alpha. J Immunol 1992; 149: 1666-1670.

15. Waage A, Halstensen A, Espevik T. Association between tumour necrosis factor in serum and fatal outcome in patients with meningococcal disease. Lancet 1987; 329: $355-357$.
16. Girardin E, Grau GE, Dayer JM, Roux-Lombard P, Lambert PH. Tumour necrosis factor and interleukin-1 in the serum of children with severe infectious purpura. N Engl J Med 1988; 319: 397-400.

17. van der Poll T, Jansen J, van Leenen D, et al. Release of soluble receptors for tumour necrosis factor in clinical sepsis and experimental endotoxemia. J Infect Dis 1993; 168: 955-960.

18. Spinas GA, Keller U, Brockhaus M. Release of soluble receptors for tumor necrosis factor (TNF) in relation to circulating TNF during experimental endotoxinemia. Clin Invest 1992; 90: 533-536.

19. van Deventer SH, Hart M, van der Poll T, Hack CE, Aarden LA. Endotoxin and tumor necrosis factor- $\alpha$-induced interleukin-8 release in humans. J Infect Dis 1993; 167: 461-464.

20. Martin GD, Danner RL, Ceska M, Suffredini AF. Detection of interleukin-8 and tumor necrosis factor in normal humans after intravenous endotoxin, the effect of antiinflammatory agents. J Exp Med 1991; 173: 1021-1024.

21. Sandström T, Bjermer L, Rylander R. Lipopolysaccharide (LPS) inhalation in healthy subjects increases neutrophils, lymphocytes, and fibronectin levels in bronchoalveolar lavage fluid. Eur Respir J 1992; 5: 992-996.

22. Cole PJ, Wilson R. Host-microbial inter-relationships in respiratory infections. Chest 1985; 95: 217S-221S.

23. Read RC, Wilson R, Rutman A, et al. Interaction of nontypable Haemophilus influenzae with human respiratory mucosa in vitro. J Infect Dis 1991; 163: 549-558.

24. Johnson AP, Inzana TJ. Loss of ciliary activity in organ cultures of rat trachea treated with lipo-oligosaccharide from Haemophilus influenzae. J Med Microbiol 1986; 22: 265-268.

25. Wilson R, Cole P. The effect of bacterial products on ciliary function. Am Rev Respir Dis 1988; 138 (Suppl): S49-S53.

26. Stockly R, Burnett D. Alpha-antitrypsin and leucocyte elastase in infected and noninfected sputum. Am Rev Respir Dis 1979; 120: 1081-1086.

27. Ras G, Wilson R, Taylor G, Cole P. Effects of bacterial products on neutrophil migration in vitro. Thorax 1990; 45: 276-280.

28. Cundell DR, Taylor GW, Kanthakumar K, et al. Inhibition of human neutrophil migration in vitro by low-molecular-mass products of nontypable $H$ influenzae. Infect Immun 1993; 61: 2419-2424.

29. Stockley RA, Hill SL, Dragicevic P, Chamba A, Burnett D. Pulmonary infections: the host response and role of indirect pathogenicity in antibiotic failure. In: Howard AJ, ed. Haemophilus influenzae; antimicrobials and the host response. Royal Society of Medicine Services International Congress and Symposium Series, 1988; 139: pp. 19-29.

30. Devalia JL, Davies RJ. Airway epithelial cells and mediators of inflammation. Respir Med 1993; 87: 405-408.

31. Devalia JL, Campell AM, Sapsford RJ, et al. Effect of nitrogen dioxide on the synthesis of inflammatory cytokines expressed by human bronchial epithelial cells in vitro. Am J Respir Cell Mol Biol 1993; 9: 271-278.

32. Kishimoto T, Hibi M, Murakami M, Narazaki M, Saito M, Taga T. The molecular biology of interleukin- 6 and its receptor. Ciba Foundation Symposium, 1992; 167: 5-16.

33. Baggiolini M., Walz A, Kunkel SL. NAP/IL-8, a novel cytokine that activates neutrophils. J Clin Invest 1989; 84: 1045-1049.

34. Detmers PA, Lo SK, Olsen-Egbert E, Walz A, Baggiolini 
M, Cohn ZA. Neutrophil-activating protein-1/interleukin-8 stimulates the binding activity of the leucocyte adhesion receptor CD11b/CD18 on human neutrophils. J Exp Med 1990; 171: 1155-1162.

35. Cromwell O, Hamid Q, Corrigan CJ, et al. Expression and generation of interleukin-8, IL-6 and granulocytemacrophage colony stimulating factor by bronchial epithelial cells and enhancement by IL- $1 \beta$ and tumour necrosis factor- $\alpha$. Immunol 1992; 77: 330-337.

36. Mullin JM, Snock KV. Effect of tumor necrosis factor on epithelial tight junctions and transepithelial permeability. Cancer Res 1990; 50: 2172-2176.

37. Springer TA. Adhesion receptors of the immune system. Nature 1990; 346: 425-434.

38. Manolitsas N, Trigg CJ, McAulay AE, et al. The expression of intercellular adhesion molecule-1 and $\beta 1$-integrins in asthma. Eur Respir J 1994; 7: 1439-1444.

39. Albelda SM. Endothelial and epithelial cell adhesion molecules. Am J Respir Cell Mol Biol 1991; 4: 195-203.

40. Khair OA, Devalia JL, Abdelaziz MM, Sapsford RJ, Tarraf $\mathrm{H}$, Davies RJ. Effect of Haemophilus influenzae endotoxin on the synthesis of IL-6, IL-8, TNF- $\alpha$ and expression of ICAM-1 in cultured human bronchial epithelial cells. Eur Respir J 1994; 7: 2109-2116.

41. Paulmichl M, Norris AA, Rainey DK. Role of chloride channel modulation in the mechanism of action of nedocromil sodium. Int Arch Allergy Appl Immunol 1995; 107: 416.

42. Sheinman BD, Devalia JL, Davies RJ, Crook SJ, Tabaqchali S. Synthesis of histamine by Haemophilus influenzae. BMJ 1986; 292: 857-858.

43. Devalia JL, Grady D, Hamanyeri Y, Tabaqchali S, Davies RJ. Histamine synthesis by respiratory tract micro-organisms: possible role in pathogenicity. J Clin Pathol 1989; 42: 516-522.

44. Devalia JL, Davies RJ. Human nasal and bronchial epithelial cells in culture: an overview of their characteristics and function. Allergy Proc 1991; 12: 71-77.

45. Wiener-Kornish JP, Albertine KH, Matthay MA. Differential responses of the endothelial and epithelial barriers of the lung in sheep to Escherichia coli endotoxin. J Clin Invest 1990; 88: 864-875.

46. Khair OA, Devalia JL, Abdelaziz MM, Sapsford RJ, Davies RJ. Effect of erythromycin on Haemophilus influenzae endotoxin-induced release of IL-6, IL-8 and sICAM-1 by cultured human bronchial epithelial cells. Eur Respir J 1995; 8: 1451-1457.

47. Sousa AR, Poston RN, Lane SJ, Nakhosteen J, Lee TH. Detection of GM-CSF in asthmatic bronchial epithelium and decrease by inhaled corticosteroids. Am Rev Respir Dis 1993; 147: 1557-1561.

48. Marini M, Vittori E, Hollemborg J, Mattoli S. Expression of the potent inflammatory cytokines, granulocyte/ macrophage colony-stimulating factor and interleukin-6 and interleukin-8, in bronchial epithelial cells of patients with asthma. J Allergy Clin Immunol 1992; 89: 1001-1009.

49. Hirano T, Kishimoto T. Molecular biology and immunology of interleukin-6. Res Immunol 1992; 143: 723-724.

50. Heremans H, Dillen C, Put W, Van Damme J, Billiau A. Protective effect of anti-interleukin (IL)-6 antibody against endotoxin, associated with paradoxically increased IL-6 levels. Eur J Immunol 1992; 22: 2395-2401.

51. Dehoux MS, Boutten A, Ostinelli J, et al. Compartmentalized cytokine production within the human lung in unilateral pneumonia. Am J Respir Crit Care Med 1994; 150: 710-716.

52. Boutten A, Dehoux MS, Seta N, et al. Compartmentalized
IL-8 and elastase release within the human lung in unilateral pneumonia. Am J Respir Crit Care Med 1996; 153: 336-342.

53. Smith EF, Slivjak MJ, Bartus JO, Esser KM. SK\&F inhibits tumor necrosis factor formation and improves survival in endotoxemic rats. J Cardiovasc Pharm 1991; 18: 721-728.

54. Doherty GM, Lange JR, Langstein HN, Alexander HR, Buresh CM, Norton JA. Evidence for IFN-gamma as a mediator of the lethality of endotoxin and tumor necrosis factor-alpha. J Immunol 1992; 149: 1666-1670.

55. Hesse DG, Tracey KJ, Fong Y, et al. Cytokine appearance in human endotoxemia and primate bacteremia. Surg Gynecol Obstet 1988; 166: 147-153.

56. Burrell R. Human responses to bacterial endotoxin. Circ Shock 1994; 43: 137-53.

57. Van Zee KJ, DeForge LE, Fischer E, et al. IL-8 in septic shock, endotoxaemia, and after IL-1 adminstration. $J$ Immunol 1991; 146: 3478-3482.

58. DeForge LE, Kenney JS, Jones ML, Warren JS, Remick DJ. Biphasic production of IL-8 in lipopolysaccharide (LPS)-stimulated human whole blood. J Immunol 1992; 148: 2133-2141.

59. Wang JH, Trigg CJ, Devalia JL, Jordan S, Davies RJ. Effect of inhaled beclomethasone dipropionate on expression of proinflammatory cytokines and activated eosinophils in the bronchial epithelium of patients with mild asthma. J Allergy Clin Immunol 1994; 94: 1025-1034.

60. Wang JH, Devalia JL, Xia C, Sapsford RJ, Davies RJ. Expression of RANTES by human bronchial epithelial cells, in vitro and in vivo, and the effect of corticosteroids. Am J Respir Cell Mol Biol 1996; 14: 27-35.

61. Dajani AS, Asmar BI, Thirmoorthi MC. Systemic Haemophilus influenzae disease: an overview. J Pediatr 1979; 94: 355-364.

62. Murphy TF, Sethi S. Bacterial infection in chronic obstructive pulmonary disease. Am Rev Respir Dis 1992; 146: 1067-1083.

63. Watson RWG, Redmond HP, Bouchier-Hayes D. Role of endotoxin in mononuclear phagocyte-mediated inflammatory response. J Leuk Biol 1994; 56: 95-103.

64. Dentener MA, Bazil V, von Asmuth EJ, Ceska M, Buurman WA. Involvement of CD14 in lipopolysaccharide-induced tumor necrosis factor- $\alpha$, IL- 6 and IL- 8 release by human monocytes and alveolar macrophages. J Immunol 1993; 150: 2885-2891.

65. Beutler BA, Krochin N, Milsark IW, Luedke C, Cerami A. Control of cachectin (tumor necrosis factor) synthesis: mechanism of endotoxin resistance. Science 1986; 232: 977-980.

66. Jirik FR, Podor TJ, Hirano T, et al. Bacterial lipopolysaccharide and inflammatory mediators augment IL-6 secretion by human endothelial cells. J Immunol 1989; 142: 144-147.

67. Nakamura M, Honda Z, Waga I, Matsumoto T, Noma $\mathrm{M}$, Shimizu T. Endotoxin transduces $\mathrm{Ca}^{2+}$ signalling via platelet-activating factor receptor. FEBS Lett 1992; 314: 125-129.

68. Herbert JM. Characterization of specific binding sites of ${ }^{3} \mathrm{H}$-labelled platelet activating factor $\left(\left[{ }^{3} \mathrm{H}\right] \mathrm{PAF}\right)$ and new antagonist, $\left[{ }^{3} \mathrm{H}\right] \mathrm{SR} 27417$, on guinea-pig tracheal epithelial cells. Biochem J 1992; 284: 201-206.

69. Adler KB, Akley NJ, Glasgow WC. Platelet-activating factor provokes release of mucin-like glycoprotein from guinea-pig respiratory epithelial cells via a lipoxygenasedependent mechanism. Am J Respir Cell Mol Biol 1992; 6: $550-556$. 
70. Chen TY, Lei MG, Suzuki T, Morrison DC. Lipopolysaccharide receptors and signal transduction pathways in mononuclear phagocytes. Curr Top Microbiol Immunol 1992; 181: 169-188.

71. Antilla HS, Reitamo S, Ceska M, Hurme M. Signal transduction pathways leading to the production of IL-8 by human monocytes are differentially regulated by dexamethasone. Clin Exp Immunol 1992; 89: 509-512.

72. Kennerly D, Duffy P. Allergy. In: Holgate ST, Church MK, eds. London, Gower Medical Publishing, 1993; 4.1

73. Karin M. The AP-1 complex and its role in transcriptional control by protein kinase C. In: Cohen P, Foulkes G, eds. Molecular Aspects of Cellular Regulation. Vol. 6. Amsterdam, Elsevier, 1990; pp. 143-161.

74. Muegge K, Durum SK. From cell to gene code: cytokines and transcription factors. New Biologist 1989; 1: 239 246.

75. Sung SJ, Walters JA, Hudson J, Gimble JM. Tumor necrosis factor-alpha mRNA accumulation in human myelonocytic cell lines: role of transcriptional regulation by DNA sequence motifs and mRNA stabilization. $J$ Immunol 1991; 147: 2047-2054.

76. Newell CI, Deisseroth AB, Lopez-Berestein G. Interaction of nuclear proteins with an AP-1/CRE-like promoter sequence in the human TNF-alpha gene. J Leuk Biol 1994; 56: 27-35.

77. Boyle WJ, Smeal T, Defize LK, et al. Activation of protein kinase $\mathrm{C}$ decreases phosphorylation of $c$-jun at sites that negatively regulate its DNA-binding activity. Cell 1991; 64: 573-584.

78. Mukaida N, Mahe Y, Matsushima K. Co-operative interaction of nuclear factor kappaB and cis-regulatory enhancer binding protein-like factor binding elements in activating the interleukin- 8 gene by proinflammatory cytokines. $J$ Biol Chem 1990; 265: 21128-21133.

79. Mukaida N, Shiroo M, Matsushima K. Genomic structure of the human monocyte-derived neutrophil chemotactic factor IL-8. J Immunol 1989; 143; 1366-1371.

80. Jonat C, Rahmsdrof HJ, Park KK, et al. Antitumor promotion and anti-inflammation: downmodulation of AP-1 (Fos/Jun) activity by glucocorticoid hormone. Cell 1990; 62: 1189-1204.
81. Yang-Yen H-F, Chambard J-C, Sun Y-L, et al. Transcriptional interference between $c$-Jun and the glucocorticoid receptor: mutual inhibition of DNA binding due to direct protein-protein interaction. Cell 1990; 62: 1205-1215.

82. Schule R, Rangarajan $\mathrm{P}$, Kliewer $\mathrm{S}$, et al. Functional antagonism between oncoprotein c-Jun and the glucocorticoid receptor. Cell 1990; 62: 1217-1226.

83. Ward P. Chemotaxis. In: Rose RR, Friedman H, eds. Manual of Clinical Immunology. Washington DC, American Society of Microbiology, 1976; p. 106.

84. Van Damme J, Rampart M, Conings R, et al. The neutrophil-activating proteins interleukin- 8 and beta-thromboglobulin: in vitro and in vivo comparison of $\mathrm{NH}_{2}$-terminally processed forms. Eur J Immunol 1990; 20: 2113-2118.

85. Koyama S, Rennard SI, Leikanf GD, et al. Endotoxin stimulates bronchial epithelial cells to release chemotactic factors for neutrophils: a potential mechanism for neutrophil recruitment, cytotoxicity, and inhibition of proliferation in bronchial inflammation. J Immunol 1991; 147: 4293-5001.

86. Koyma S, Rennard SI, Robbins RA. Acetylcholine stimulates bronchial epithelial cells to release neutrophil and monocyte chemotactic activity. Am J Physiol 1992; 262: 466-471.

87. Bellini A, Yoshimura H, Vittori E, Marini M, Mattoli S. Bronchial epithelial cells of patients with asthma release chemoattractant activity for T-lymphocytes. J Allergy Clin Immunol 1993; 92: 412-424.

88. Robbins RA, Shoji S, Linder J, et al. Bronchial epithelial cells release chemotactic activity for lymphocytes. Am J Physiol 1989; 257: L109-115.

89. Koyama S, Rennard SI, Shoji S, et al. Bronchial epithelial cells release chemoattractant activity for monocytes. Am J Physiol 1989; 257: L130-136.

90. Schleimer RP, Sterbinsky SA, Kaiser J, et al. IL-4 induces adherence of human eosinophils and basophils but not neutrophils to endothelium. Association with expression of VCAM-1. J Immunol 1992; 148: 1086-1092.

91. Bochner BS, Luscinskas FW, Gimbrone MA, et al. Adhesion of human basophils, eosinophils, and neutrophils to interleukin-1-activated human vascular endothelial cells: contribution of endothelial cell adhesion molecules. $J$ Exp Med 1991; 173: 1553-1556. 